\title{
An Assessment on the Intensive Land Use by Universities—-Take the 985 Project Universities as Examples
}

\author{
Zhang Li*, Du Meng \\ School of Economics, Shanghai University, Shanghai, China \\ Email address: \\ 1526589846@qq.com (Zhang Li), 506123487@qq.com (Du Meng) \\ ${ }^{*}$ Corresponding author
}

\section{To cite this article:}

Zhang Li, Du Meng. An Assessment on the Intensive Land Use by Universities_- Take the 985 Project Universities as Examples. Science Innovation. Vol. 4, No. 2, 2016, pp. 88-94. doi: 10.11648/j.si.20160402.22

Received: April 2, 2016; Accepted: April 14, 2016; Published: April 19, 2016

\begin{abstract}
This paper makes an analysis on the basic status and changing trend of the intensive land use by China's universities from 2005 to 2012. An assessment indicator system of the intensive land use is built, and the research samples are the 985 project universities in China. The result indicates that the degree of the intensive land use by the 985 project universities has improved slightly than before, but the overall level is still low. The degrees in different areas even in different universities of the same area vary a lot.
\end{abstract}

Keywords: Land of Universities, Intensive Use, Assessment

\section{高校土地集约利用评价一一以“985”高校为例}

张笠*，杜萌

经济学院, 上海大学, 上海, 中国

\section{邮箱}

1526589846@qq. com(张笠), 506123487@qq. com(杜萌)

摘要: 本文通过构建高校土地集约利用评价指标体系, 选取中国 “985” 高校作为研究样本, 分析了目前中国高校土地 集约利用的基本情况以及从 2005 年到 2012 年的变化情况, 发现目前中国 “985” 高校土地集约利用程度相比之前略有提 高、但整体水平仍不高，不同地区之间甚至同一地区内部各高校土地利用集约度的差异性较大。

关键词: 高校土地, 集约利用, 评价

\section{1. 引言}

人多地少，用地紧张一直是中国普遍存在的问题，高 校土地的利用也不例外。近年来, 高等教育体制的改革, 大规模地扩大了招生的数量, 用地矛盾也不断突出。因此, 高校土地的用地问题得到了社会各方的普遍关注，同时也
是《国土资源调查评价 “十二五” 规划》确定的重点工作 任务。2011年, 国土资源部选取了北京大学、吉林大学等 6所高校作为第一批高校用地集约利用评价的试点, 并且 颁布了《高校教育用地集约利用评价技术指南 (试行)》; 2012年，国土资源部对上海、南昌、南宁三市的高校进行 了第二批的土地集约利用评价工作。由此可见，建立合理 
的高校用地评价标准，对高校土地进行集约利用评价就显 得十分必要和迫切。

\section{2. 文献综述}

\section{1. 土地集约利用的概念}

土地的不可再生性与人类数量的不断增长必然导致 土地供给与土地需求的逐渐失衡, 为了满足人类生存与发 展的基本需求, 土地的集约利用就有了重要的意义 [1-2]。 随着社会、经济、科技水平和人类认知水平的发展, 部分 学者立足于具体评价对象和评价区域的特点提出了农用 地集约利用和建设用地集约利用的内涵 [3]。由于中国人 多地少的基本国情以及快速城镇化进程中人地矛盾的加 剧, 城市土地集约利用已经成为目前亟待解决的问题。城 市土地集约利用潜力的评价可以分宏观、中观、微观三个 层次, 宏观层次的评价是对一个城市土地集约利用水平的 总体评价, 中观层次是对城市内部某个区域的评价, 微观 层次则是对具体地块的评价 [4]。但是目前对于城市土地 集约利用内涵存在两种观点, 一种是认为集约利用完全属 于经济范畴, 主要目标是通过增加土地投入来增加经济效 益; 另一种认为土地集约利用不完全是经济范畴, 不仅仅 注重经济效益还要不断提高土地的环境效益和社会效益, 是强调综合效益的动态过程 [5]。

\section{2. 土地集约利用评价的内涵}

顾名思义，土地集约利用评价即是对土地利用方式进 行的集约度的综合评价。因此可以将其定义成, 通过对符 合相关法律、政策、规划等要求下, 增加土地投入, 改善 土地经营管理, 挖掘土地利用潜力, 不断提高土地经济效 益的土地利用方式而进行的科学的、系统的、全面的评价, 并以此来不断提高土地的集约利用程度 [6]。土地集约利 用评价应该遵循的原则有合理利用原则、综合性原则、定 性分析与定量分析相结合的原则、主导因素原则、可操作 性原则以及动态导向性和弹性原则 [7]。

\section{3. 高校土地集约利用评价}

目前, 对于高等学校而言, 由于高等教育的“大众化”, 各大高校纷纷进行了扩建, 然而这些变化却带来了一些问 题。首先, 原校区因为土地供应的短缺, 为了更好的适应 高校的运营, 必须增加投入强度、优化利用结构、提高使 用效率、加强土地利用的集约化。对于新建校区, 由于是 国家划拨的, 土地面积大, 成本小, 加之大多数高校缺乏 长远而合理的规划布局, 从而导致了高校土地空置率较高, 布局结构混乱, 甚至很多已建成的硬件设施使用率仍很低。 因此, 高校土地利用就陷入了一个恶性循环, 由于招生人 数的扩大, 导致校园的扩建, 而扩建的校园的集约利用程 度很低又会继续进行扩建, 这一系列的循环必然加剧人地 矛盾, 所以对高校土地集约利用的评价就显得十分必要和 迫切。

近年来, 很多专家学者都对高校土地集约利用展开了 研究。马玉梅、马晓林分别从投入与产出两个方构建了高 校教育用地集约利用社会效益评价指标体系, 并建议对研
究型和教学型高校分设不同的理想标准 [8]; 陈思、李淑 杰等专家以长春市 15 所高校为对象, 研究发现长春高校土 地总体利用水平较高, 少数高校集约度较低, 同时呈现出 城市中心区域向城市边缘区域衰减的趋势 [9]; 李淑杰等 学者又以吉林大学为例, 运用可拓物元模型定量研究教育 用地集约利用程度, 研究表明该方法在研究土地集约利用 程度上具有较高的应用价值 [10]; 张亚丽、翟晓艺学者则 是以高等学校老校区为研究对象, 帮助老校区重新明确功 能定位, 进行资源优化重组 [11]。

\section{3. 高校土地集约利用评价指标体系的构建}

\section{1. 评价指标体系构建的原则和基本思路}

土地集约利用评价指标体系是一个复杂的动态系统 [12]。为了使评价结果更加的准确而科学, 评价指标的选 取应该遵循以下几个原则: 一是全面性和多样性, 土地集 约利用评价涉及很多方面, 因此评价指标必须兼顾各个方 面; 二是前瞻性和引导性, 评价指标应该尽可能反映高校 土地利用的趋势和方向, 能够促进高校土地的合理有效利 用; 三是先进性和可行性, 既要考虑到数据的可获得性又 要是指标的先进性; 四是针对性和具体性, 在众多指标中 选取最能体现高校土地利用现状和问题的指标 [13]。根据 土地集约利用的内涵以及高校土地集约利用的特殊性, 本 文将从土地利用强度、土地投入强度以及土地产出效率来 构建指标体系, 由于受数据的限制, 在此忽略了土地利用 结构的指标 [14-15]。根据相关研究进展以及高校土地利 用标准的分析, 土地利用强度主要考虑生均占地面积和容 积率, 土地投入强度主要考虑单位面积的科研经费和科研 人员, 土地产出效率主要考虑单位面积的科研课题以及授 奖成果。考虑到 985 高校的分布情况以及部分学校自身的 特殊性, 将对其进行进一步衡量。下面从目标层、准则层、 指标层三个大的层次, 共有 6 个指标因子构建 “985” 高校 的指标体系 $[16]$ 。（表1）

\section{2. 指标权重的确定}

“985”高校指标体系中各项指标权重的确定将采用 层次分析法 (AHP)。首先, 通过将问题条理化、层次化, 构造出目标层、准则层和指标层, 再通过经验丰富的专业 人员对不同指标进行比较确定出判断矩阵 $\mathrm{A}$, 接着用方根 法计算权重矢量, 最后进行一致性检验 $(\mathrm{CR}=\mathrm{CI} / \mathrm{RI})$, 获 得 “985” 高校土地集约利用评价指标体系权重值表格。 (表2)

\section{3. 评价指标标准化处理}

Li 具有负相关时, $L i=(b i-x i) /(a i-b i)$

$\mathrm{Li}$ 具有正相关时, $L i=(x i-b i) /(a i-b i)$

其中 Li $(i=1,2,3, \cdots, n)$ 为高校土地集约利用评价指 标标准化值, $x i(i=1,2,3, \cdots, n)$ 为评价指标变量值, ai, bi为该指标的上下限。

在该评价体系中, 各指标的上下限分别采用所评价高 校中的最高值和最低值 [17-18]。 


\section{4. 集约度综合分值的计算方法}

“985”高校土地利用集约度子目标分值的计算：

$$
\mathrm{Hi}=\sum \mathrm{Li} \times \mathrm{Wi}
$$

$\mathrm{Hi}$ 为某一准则层子目标的分值, $\mathrm{Li}$ 为评价指标变量值 的标准化值, Wi为该指标层所对应的权重。
“985”高校土地利用集约度综合分值的计算:

$$
\mathrm{C}=\sum \mathrm{Hi} \times \mathrm{Vi}
$$

$\mathrm{C}$ 为高校土地利用集约度综合分值, $\mathrm{Vi}$ 为该准则层所 对应的权重 [19]。

按照上述方法，可以计算出39所 “985” 高校土地利 用集约度综合分值。

\begin{tabular}{|c|c|c|c|c|}
\hline 目标层 & 准则层 & 指标层 & 含义 & 公式 \\
\hline \multirow{6}{*}{$\begin{array}{l}\text { “985”高校土地利用 } \\
\text { 集约程度 }\end{array}$} & 土地利 & 人口密度 $\left(\right.$ 人 $\left./ \mathrm{hm}^{2}\right)$ & \multirow{6}{*}{$\begin{array}{l}\text { 学校单位占地面积上拥有的全日制学 } \\
\text { 生人数, 与评价目标正相关 } \\
\text { 容积率直接反映出了土地的利用情况, } \\
\text { 与评价目标正相关 } \\
\text { 学校单位占地面积上所拥有的科研人 } \\
\text { 员数量, 与评价目标正相关 } \\
\text { 学校单位占地面积上所拥有的科研经 } \\
\text { 费数量, 与评价目标正相关 } \\
\text { 学校单位占地面积上所拥有的科技课 } \\
\text { 题数, 与评价目标正相关 } \\
\text { 学校单位占地面积上所有用的授奖成 } \\
\text { 果数量, 与评价目标正相关 }\end{array}$} & $\begin{array}{l}\text { 人口密度=学校全日制学生人数/学校占 } \\
\text { 地面积 }\end{array}$ \\
\hline & 用强度 & 容积率 & & 容积率=学校建筑面积/学校占地面积 \\
\hline & 土地投 & $\begin{array}{l}\text { 单位面积的教学与研究 } \\
\text { 人员 }\left(\text { 人 } / \mathrm{hm}^{2}\right)\end{array}$ & & $\begin{array}{l}\text { 单位面积的教学与研究人员=学校教学 } \\
\text { 与科研人员数量/学校占地面积 }\end{array}$ \\
\hline & 入强度 & $\begin{array}{l}\text { 单位面积的科技经费 } \\
\left(\text { 千元 } / \mathrm{hm}^{2}\right)\end{array}$ & & $\begin{array}{l}\text { 单位面积的科技经费=学校科研经费数 } \\
\text { 量/学校占地面积 }\end{array}$ \\
\hline & 土地产 & $\begin{array}{l}\text { 单位面积的科技课题 } \\
\left(\text { 项 } / \mathrm{hm}^{2}\right)\end{array}$ & & $\begin{array}{l}\text { 单位面积的科技课题=学校科技课题数 } \\
\text { 量/学校占地面积 }\end{array}$ \\
\hline & 出效率 & $\begin{array}{l}\text { 单位面积的成果授奖 } \\
\left(\text { 项 } / \mathrm{hm}^{2}\right)\end{array}$ & & $\begin{array}{l}\text { 单位面积的成果授奖=学校授奖成果数 } \\
\text { 量/学校占地面积 }\end{array}$ \\
\hline
\end{tabular}

表1“985”高校土地集约利用评价指标体系。

表2 “985”高校土地集约利用评价指标体系权重值。

\begin{tabular}{lllll}
\hline 目标层 & 准则层 & 权重 & 指标层 & 权重 \\
\hline & 土地利用强度 & \multirow{2}{*}{0.327} & 人口密度 & 0.485 \\
& & & 容积率 & 0.515 \\
& & \multirow{2}{*}{0.335} & 单位面积的研究人员 & 0.515 \\
& & & 单位面积的科研经费 & 0.485 \\
& & 土地投入强度 & 单位面积的科研课题 & 0.529 \\
& 土地产出效率 & \multirow{2}{*}{0.338} & 单位面积的授奖成果 & 0.471 \\
\hline
\end{tabular}

\section{4. 数据分析与评价}

\section{1. 评价基本思路}

“985”高校象征着目前国内大学的最高水平, 无论 在科技研究还是经营管理方面都有着先锋模范作用, 因此 对中国的 “985” 高校进行土地集约利用评价，首先是可 以对高水平高校的土地集约利用程度有一个初步了解, 同 时更加是以此为代表引起所有高校对土地集约利用的关 注, 进而不断调整高校土地利用结构, 改善高校土地经营 管理, 提高高校土地集约利用程度, 甚至可以以学校为起 点带动所在城市的土地集约利用。

本文主要是以 39 所 “985” 高校为研究对象, 统计了 这些高校在 2005 年和 2012 年的占地面积、校舍面积、全日 制学生数、科研人员、科研经费、科研课题以及授奖成果。 再根据上述的评价方法得出 “985” 高校在不同年份土地 利用集约度综合分值。从横向对比分析目前不同地区高水 平高校的土地利用集约程度，同时在纵向上分析从 2005 年到2012年这批高校的土地利用集约程度的变化, 即对中 国 “985” 高校土地集约利用的时空差异的研究 [20]。

\section{2. 数据处理结果}

\begin{tabular}{|c|c|c|c|c|c|c|c|c|c|}
\hline \multirow{2}{*}{ 地区 } & \multirow{2}{*}{ 学校 } & \multicolumn{2}{|c|}{ 土地利用强度 } & \multicolumn{2}{|c|}{ 土地投入强度 } & \multicolumn{2}{|c|}{ 土地产出效率 } & \multicolumn{2}{|c|}{ 集约度综合分值 } \\
\hline & & 2005 & 2012 & 2005 & 2012 & 2005 & 2012 & 2005 & 2012 \\
\hline \multirow{4}{*}{ 东北地区 } & 东北大学 & 0.281 & 0.304 & 0.102 & 0.214 & 0.211 & 0.258 & 0.197 & 0.259 \\
\hline & 大连理工大学 & 0.312 & 0.173 & 0.114 & 0.131 & 0.365 & 0.209 & 0.263 & 0.171 \\
\hline & 吉林大学 & 0.239 & 0.225 & 0.058 & 0.144 & 0.098 & 0.131 & 0.131 & 0.166 \\
\hline & 哈尔滨工业大学 & 0.157 & 0.195 & 0.096 & 0.131 & 0.141 & 0.158 & 0.131 & 0.161 \\
\hline \multirow{6}{*}{ 华北地区 } & 清华大学 & 0.197 & 0.178 & 0.147 & 0.300 & 0.230 & 0.416 & 0.191 & 0.299 \\
\hline & 北京大学 & 0.262 & 0.332 & 0.154 & 0.523 & 0.204 & 0.311 & 0.206 & 0.389 \\
\hline & 中国人民大学 & 0.622 & 0.710 & 0.003 & 0.036 & 0.000 & 0.056 & 0.204 & 0.263 \\
\hline & 北京理工大学 & 0.576 & 0.468 & 0.355 & 0.414 & 0.421 & 0.351 & 0.450 & 0.411 \\
\hline & 北京航空航天大学 & 0.517 & 0.273 & 0.221 & 0.264 & 0.604 & 0.381 & 0.447 & 0.306 \\
\hline & 北京师范大学 & 0.463 & 0.610 & 0.142 & 0.301 & 0.120 & 0.481 & 0.240 & 0.463 \\
\hline
\end{tabular}

表3 2012与2005年中国 “985”高校土地集约利用评价表。 


\begin{tabular}{|c|c|c|c|c|c|c|c|c|c|}
\hline \multirow{2}{*}{ 地区 } & \multirow{2}{*}{ 学校 } & \multicolumn{2}{|c|}{ 土地利用强度 } & \multicolumn{2}{|c|}{ 土地投入强度 } & \multicolumn{2}{|c|}{ 土地产出效率 } & \multicolumn{2}{|c|}{ 集约度综合分值 } \\
\hline & & 2005 & 2012 & 2005 & 2012 & 2005 & 2012 & 2005 & 2012 \\
\hline \multirow{15}{*}{ 华东地区 } & 中国农业大学 & 0.402 & 0.391 & 0.125 & 0.259 & 0.270 & 0.459 & 0.264 & 0.370 \\
\hline & 中央民族大学 & 0.644 & 0.910 & 0.028 & 0.037 & 0.002 & 0.009 & 0.220 & 0.313 \\
\hline & 天津大学 & 0.401 & 0.260 & 0.180 & 0.327 & 0.304 & 0.422 & 0.294 & 0.337 \\
\hline & 南开大学 & 0.359 & 0.404 & 0.095 & 0.165 & 0.176 & 0.187 & 0.208 & 0.250 \\
\hline & 厦门大学 & 0.139 & 0.062 & 0.014 & 0.029 & 0.039 & 0.050 & 0.064 & 0.047 \\
\hline & 南京大学 & 0.177 & 0.259 & 0.058 & 0.180 & 0.111 & 0.160 & 0.115 & 0.199 \\
\hline & 东南大学 & 0.360 & 0.152 & 0.203 & 0.179 & 0.236 & 0.244 & 0.265 & 0.192 \\
\hline & 复旦大学 & 0.211 & 0.552 & 0.097 & 0.991 & 0.286 & 0.785 & 0.198 & 0.778 \\
\hline & 同济大学 & 0.230 & 0.295 & 0.133 & 0.318 & 0.268 & 0.369 & 0.210 & 0.328 \\
\hline & 上海交通大学 & 0.101 & 0.221 & 0.151 & 0.466 & 0.247 & 0.579 & 0.167 & 0.424 \\
\hline & 华东师范大学 & 0.154 & 0.235 & 0.037 & 0.070 & 0.071 & 0.104 & 0.087 & 0.135 \\
\hline & 山东大学 & 0.276 & 0.385 & 0.060 & 0.194 & 0.162 & 0.283 & 0.165 & 0.287 \\
\hline & 中国海洋大学 & 0.096 & 0.235 & 0.062 & 0.127 & 0.089 & 0.091 & 0.082 & 0.150 \\
\hline & 浙江大学 & 0.088 & 0.177 & 0.092 & 0.376 & 0.337 & 0.418 & 0.174 & 0.325 \\
\hline & 中国科学技术大学 & 0.268 & 0.245 & 0.140 & 0.261 & 0.140 & 0.243 & 0.182 & 0.250 \\
\hline \multirow{4}{*}{ 华中地区 } & 武汉大学 & 0.309 & 0.352 & 0.112 & 0.231 & 0.225 & 0.350 & 0.215 & 0.311 \\
\hline & 华中科技大学 & 0.256 & 0.278 & 0.107 & 0.247 & 0.153 & 0.286 & 0.171 & 0.270 \\
\hline & 湖南大学 & 0.482 & 0.398 & 0.125 & 0.205 & 0.234 & 0.238 & 0.278 & 0.279 \\
\hline & 中南大学 & 0.466 & 0.292 & 0.172 & 0.255 & 0.280 & 0.300 & 0.305 & 0.282 \\
\hline \multirow{2}{*}{ 华南地区 } & 中山大学 & 0.059 & 0.110 & 0.047 & 0.186 & 0.067 & 0.177 & 0.058 & 0.158 \\
\hline & 华南理工大学 & 0.166 & 0.279 & 0.083 & 0.161 & 0.133 & 0.324 & 0.127 & 0.255 \\
\hline \multirow{4}{*}{ 西北地区 } & 西安交通大学 & 0.445 & 0.448 & 0.167 & 0.348 & 0.295 & 0.508 & 0.301 & 0.435 \\
\hline & 兰州大学 & 0.000 & 0.084 & 0.013 & 0.044 & 0.035 & 0.082 & 0.016 & 0.070 \\
\hline & 西北工业大学 & 0.778 & 0.217 & 0.332 & 0.201 & 0.835 & 0.226 & 0.648 & 0.215 \\
\hline & 西北农林科技大学 & 0.092 & 0.074 & 0.065 & 0.079 & 0.101 & 0.041 & 0.086 & 0.065 \\
\hline \multirow{3}{*}{ 西南地区 } & 重庆大学 & 0.167 & 0.193 & 0.064 & 0.074 & 0.091 & 0.130 & 0.107 & 0.132 \\
\hline & 四川大学 & 0.216 & 0.247 & 0.111 & 0.214 & 0.142 & 0.297 & 0.156 & 0.253 \\
\hline & $\begin{array}{l}\text { 电子科技大学 } \\
\text { 国防科学技术大学 }\end{array}$ & 0.883 & 0.198 & 0.251 & 0.121 & 0.392 & 0.123 & 0.505 & 0.147 \\
\hline
\end{tabular}

注: 数据来自于学校官方网站、《中国高等学校大全》系列丛书以及中华人民共和国教育部科学技术司相关年份的统计结果, 国防科技大学的相关 数据无从获得。

\section{3. 时空分析}

\section{3. 1. 基于Arcgis分析得出的 2012 年各地区 “985” 高校土地集约利用的基本情况}

2012年各大地区“985”高校土地利用强度分布图

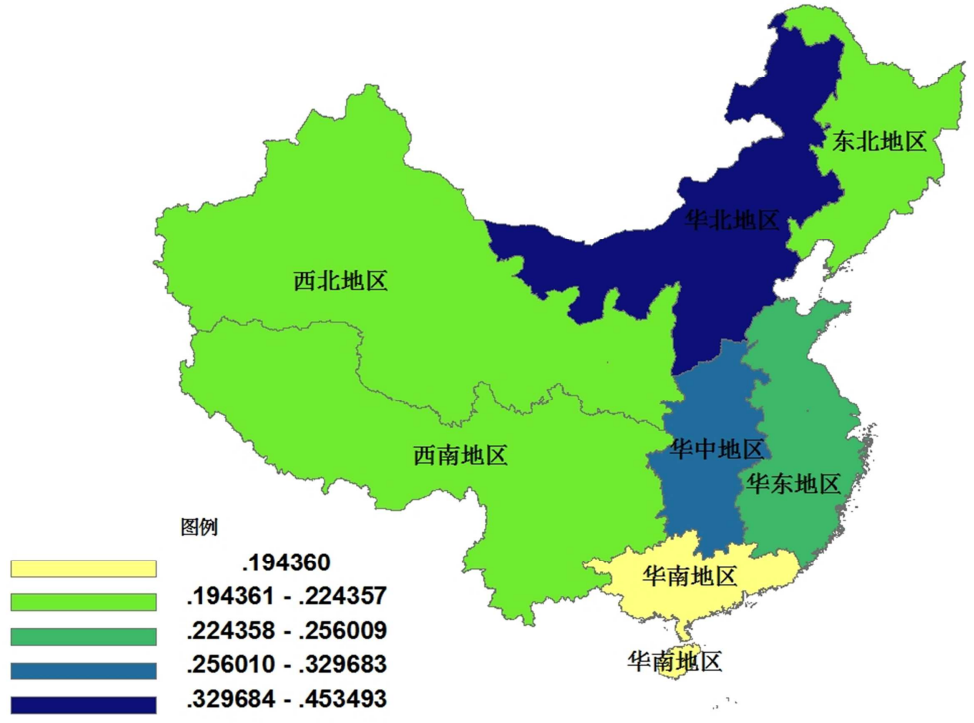

图1 2012年各大地区 “985” 高校土地利用强度分布图。 


\section{2年各大地区“985”高校土地投入强度分布图}

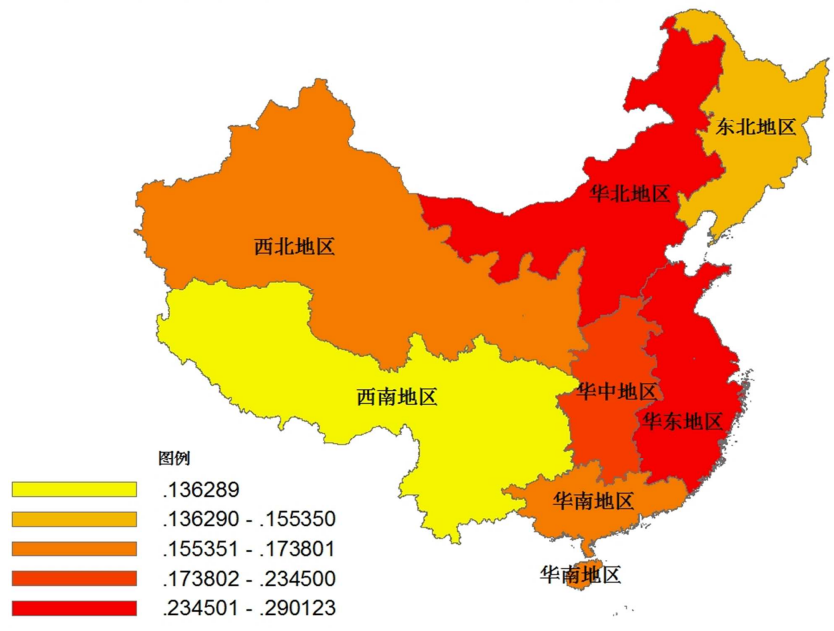

图2 2012年各大地区 “985” 高校土地投入强度分布图。

\section{2年各大地区“985”高校土地产出效率分布图}

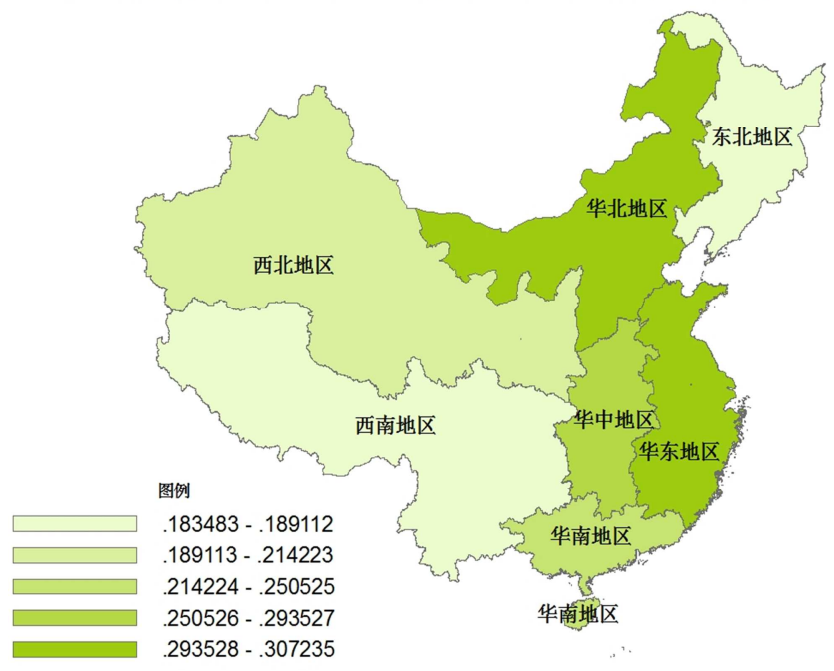

图3 2012年各大地区 “985” 高校土地产出效率分布图。

从图1, 图2和图3可以直观地看出目前中国 “985” 高 校土地集约利用的基本情况。从整体的土地利用集约程度 看, 华北地区的 “985” 高校的集约度综合分值最高, 之 后依次是华中、华东、华南、西北、东北和西南地区。从 图中可以看出不同地区的 “985” 高校土地集约利用程度 相差较大。如果仅从土地使用强度方面看, 华北地区的 “985” 高校是强度最高的, 之后依次是华中、华东、东 北、西南、西北和华南地区; 如果仅从土地投入强度方面 看, 做的最好的是华东地区的高校, 之后依次是华北、华 中、华南、西北、东北和西南地区; 如果从产出效率方面 看, 效率最高的是华北地区的 “ 985 ” 高校, 之后依次是 华东、华中、华南、西北、东北和西南地区。如果考察单 个学校, 从表 3 中可以看出复旦大学整体的土地集约利用 程度最高, 而厦门大学的集约度是最低的, 并且他们同属 于华东地区, 因此即使是同一地区的 “985” 高校土地集 约利用程度也是存在很大差距的。

\section{3. 2. 对比分析 2005 年和 2012 年 “ $985 ”$ 高校土地集约利 用程度的变化}

纵观 “985” 高校土地集约利用程度的平均水平, 2012 年的综合集约程度要比 2005 年的程度高, 分块来看, 2012 年虽然土地投入强度、土地产出效率要高于 2005 年, 但是 最直接的土地利用强度却不如 2005 的高。

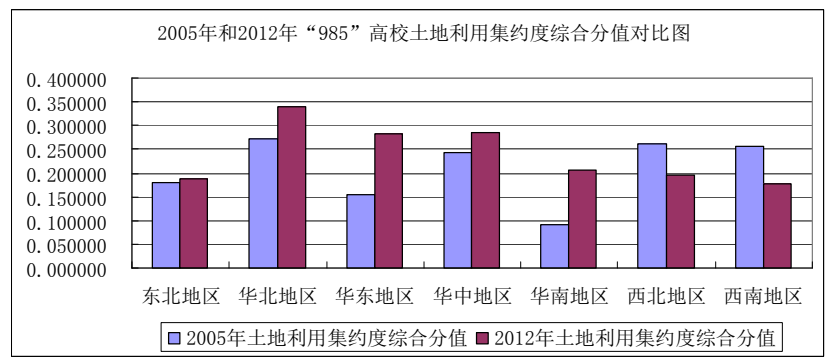

图4 2005年和2012年 “985” 高校土地利用集约度综合分值对比图。

从图4中可以看出, 2012年 “985” 高校的土地利用集 约度综合分值总体上要比 2005 年的高, 只有西北地区和西 南地区的综合集约度要比 2005 年的差, 其他地区的综合集 约度都比2005年的程度要有所提高。对于西北地区和西南 地区降低的原因, 从统计数据中分析可知, 主要原因是部 分学校在2005至2012年间大范围的扩建了校园, 但是科研 投入和科研成果的增加却远远不及校园面积增加的比例。 其中最突出的就是四川的电子科技大学, 占地面积从原来 的60公顷增加到270多公顷, 但是校舍面积, 全日制学生 数以及科研经费、课题、成果增加的却并不多, 这也就导 致了该大学从 2005 年的土地综合集约利用程度名列前茅 跌倒2012年的集约度倒数。

下面从不同的指标层分析 2005 年和 2012 年 “985” 高 校土地集约利用程度的变化:

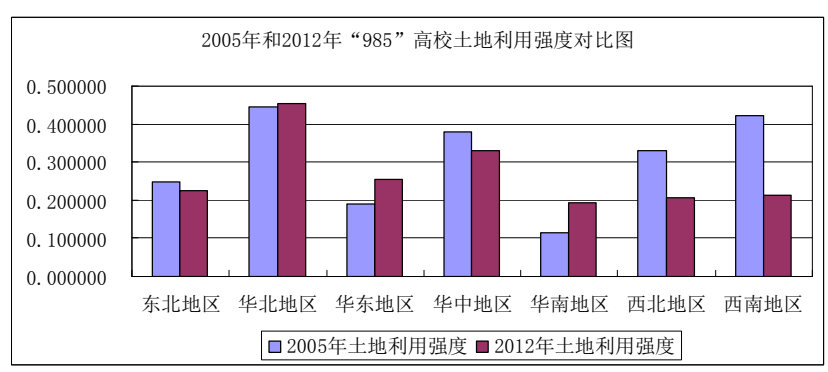

图5 2005年和2012年 “985” 高校土地利用强度对比图。

从图5可以看出, 2012年 “985” 高校土地利用强度的 整体水平要低于 2005 年水平, 其中西北地区和西南地区下 降程度较大, 华东地区和华南地区的利用强度略有上升, 其他地区的利用强度变化不大。对于西北和西南地区, 2005年 “985” 高校的土地利用强度本身比较高, 部分学 校占地面积还很小, 但是由于这些地区本身面积辽阔、土 地开发程度低, 很多学校得以大面积扩建, 加之学校的校 舍面积和学生数量增加比例相对较低, 这就导致了这些地 区的土地利用强度大幅下滑。对于华东和华南地区, 2005 年 “985” 高校的土地利用强度本身较低, 部分学校的占 
地面积已经很大, 同时这些地区土地利用紧张, 能够再转 为高校用地的土地已经不多, 所以这些地区的高校主要以 在原有校园里建设校舍为主, 这也就促进了这些地区高校 的土地利用强度的提高。

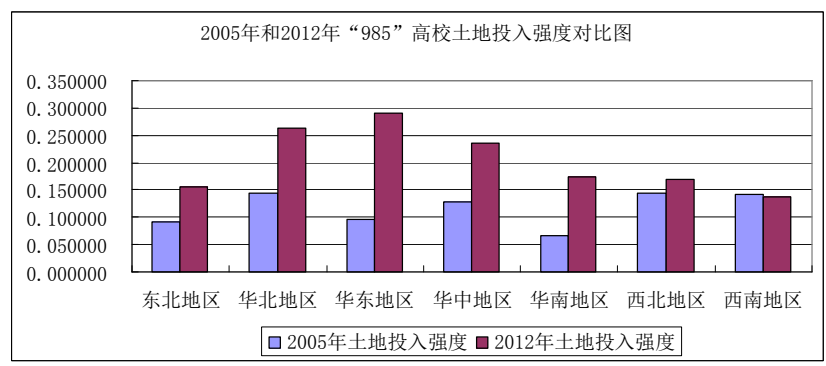

图6 2005年和2012年 “985” 高校土地投入强度对比图。

从图6可以看出, 2012年 “985” 高校的土地投入强度 普遍要比2005年的高, 除了西南地区略有一点点下跌, 其 他地区都有上升，其中华北、华东、华中和华南地区上升 比例很高。本文认为, 中国整体水平都有上升的原因主要 是国家和政府对高水平学校的科研水平越来越重视, 无论 是高校科研人员的数量还是科研经费的数量都有较大幅 度的提高, 因此相较于 2005 年, 2012年的土地投入强度普 遍都有提高。之所以华北、华东、华中和华南地区的土地 投入强度增加较多, 主要是因为这些地区经济比较发达, 能够吸引的高等科研人员较多, 同时富裕的地区政府投入 的科研经费也就相应较多。

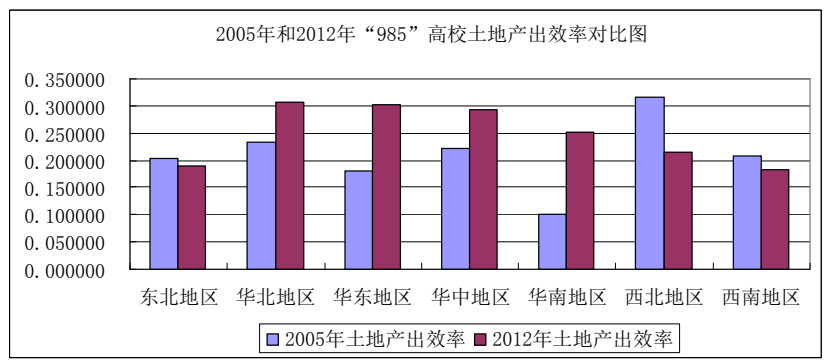

图7 2005年和2012年 “985” 高校土地产出效率对比图。

从图7可以看出, 总体来说, 2012年 “985” 高校土地 产出效率要比 2005 的时候高, 其中华北、华东、华中和华 南地区的产出效率都有所增加, 华南地区增长飞速, 而东 北、西北和西南地区的土地产出效率却都有所下降, 西北 地区下降最大。结合上面土地投入强度的图分析可以发现, 华北、华东、华中和华南地区高校土地产出效率的提高主 要是因为土地投入强度的不断提高, 然而西北地区土地产 出效率反而随着土地投入强度的提高而下降, 这可能涉及 到西北地区 “985”高校的资源利用效率等一系列的问题。

综上所述，从整体上看，2012年的 “985”高校土地 集约利用程度要比2005的情况好, 但是细细分析, 我们可 能会有一些疑问。首先, 如果仅从土地利用强度方面看, 也就是在直接反映高校土地利用情况上看, 2012年的情况 是不如 2005 年的状况好的。同时虽然在土地投入强度和土 地产出效率上看都有明显的好转, 但是如果考虑中国2005 年到2012年经济水平的快速发展, 土地的投入强度的变化
可能要大打折扣, 同样的土地产出效率的指标也会受到期 间相关国家政策的影响。因此, 本文想要在此说明的观点 就是虽然根据此评价体系的结果显示中国 “985” 高校土 地集约利用程度有所提高, 但是事实上我们仍然面临着严 峻的高校土地利用问题。

\section{4. 评价结果综合分析}

\section{4. 1. 中国 “ $985 ”$ 高校土地利用特点分析}

一方面, 横向分析 2012 年的数据, 可以得出目前中国 “985”高校土地利用状况的特点。第一, 中国各地区“985” 高校的土地集约利用综合分值差异性较大, 个别高校之间 的跨度极大，这反映了各地区高校之间的土地资源、科技 经费等项目分布不均衡。第二, 即使是同一地区的 “985” 高校的土地集约利用程度也相差很大, 例如复旦大学和厦 门大学都属于华东地区, 但是分别是综合集约度最高的高 校和最低的高校。这说明即使同一地区资源分配也存在不 均衡。第三，各地区 “985” 高校土地利用集约度综合分 值的平均值普遍不高, 主要是因为高校用地的取得方式都 是行政划拨, 具有无偿性, 并且学校凭借身份的特殊性不 存在对建设项目明确的指标限定, 这就促使了大部分高校 对土地集约利用的意识不高, 缺乏统一合理的规划引导, 进而集约化程度低下。

另一方面, 纵向分析 2005 年和 2012 年的数据, 可以发 现 “985” 高校的土地集约利用程度的变化。第一，不同 地区 “985” 高校的土地集约利用程度的变化不一样, 有 提高有降低, 即使同一区域的高校的变化情况也不一样, 这说明学校规划建设具有自主性, 不存在统一的政策引导, 也不存在区域性的规划安排。第二，相比于2005年，2012 年 “985” 高校土地集约利用评价的综合结果有所提升, 但是就土地利用强度来说，2012年是不如2005年的。同时 虽然整体水平在进步, 但是也存在部分学校的集约度综合 分值有所降低的情况。第三, 虽然评价结果显示高校的土 地集约利用程度在提高, 但是整体上仍然处于一个较低水 平，存在很大的发展空间。第四，根据数据统计，“985” 高校的全日制学生数、校舍面积、科研人员和经费以及科 研课题和成果的绝对值大体都在增加, 这些都说明此类高 校在土地集约利用方面的潜力很大。

\section{4.2. “985” 高校土地集约利用过程中存在的问题}

总体来说, 由于学校土地获得的无偿性, 导致了大多 数高校缺乏土地集约利用的意识, 同时因为国家没有对高 校土地建设方面明确的硬性规定和有效的规划引导, 因此 目前 “985” 高校土地集约利用程度普遍低下，大部分高 校土地利用结构不合理, 土地利用方式太简单。

具体可以分为以下几个方面：第一，从中国 “985” 高校本身来看, 土地的集约利用程度普遍偏低, 各高校的 容积率还有待提升, 人口密度也没有到瓶颈, 土地资源的 闲置率还比较高, 利用结构也不尽合理, 这其中有学校的 历史沿袭的因素, 也有缺乏规划布局以及政策引导的原因。 第二, 各地区以及各高校之间教育资源的分配不够均衡。 第三, 就城市而言, 各地区 “985” 高校的土地集约利用 程度差异性较大, 而且很多高校的建设发展并没有与所处 
城市的特点相适应, 这对整个城市的土地利用都有较大的 影响。第四, 对于政府来说, 行政划拨的方式让高校获得 土地太过轻易, 让其很难意识到土地的宝贵价值, 从而就 很难在建设中充分发挥集约利用的原则。第五, 政府对于 高校用地标准存在很大问题, 首先现行的高校用地标准基 本沿袭了几十年前颁布的 “生均一分地” 的设学标准, 这 个已经严重脱离了土地国情 [21], 其次对于各种用地类型 的划分以及用地的标准也缺乏相对统一的硬性规定, 同时 也没有充分考虑到学校性质的差异, 这就导致了高校之间 在集约度方面的差异性。第六, 目前国内尚没有统一的土 地集约利用评价指标体系, 更加没有关于 “高校” 的评价 指标体系, 所以目前对高校土地集约利用的关注程度并不 高, 这也就导致了高校土地集约利用程度普遍偏低的状况。

\section{5. 结论和建议}

分析“985”高校的土地集约利用评价结果可以看出, 目前中国 “985” 高校土地集约利用程度相比之前略有提 高、但整体水平仍不高，不同地区之间甚至同一地区内部 各高校土地利用集约度的差异性较大。

通过对中国 “985” 高校的土地集约利用评价结果的 综合分析, 结合上述总结的问题, 主要针对高校缺乏土地 集约利用的意识、地区间教育资源分配不均以及与相关政 策法规等问题提出相应的对策与建议，具体如下:

1. 制定科学的高等学校用地标准

2. 加快构建高等学校土地集约利用评价的指标体系

3. 建立完善的高等学校用地审批制度

4. 加强对高校土地利用的管控

5. 均衡教育资源

6. 加强政府的引导和学校的规划

7. 其他促进高校土地集约利用的措施

\section{参考文献}

[1] Steven A. Gabriel, Jose' A. Faria, Glenn E. Moglen, A multiobjective optimization approach to smart growth in land development $[\mathrm{J}]$. Socio-Economic Planning Sciences, 2006, (40) : 212-248.

[2] W. C. Wheaton, Urban spatial development with durable but replaceable capital [J]. Journal of Urban Economics, 1982, (12) : 53-67.

[3] 钱铭杰, 王绪龙, 孙玉晶, 等. 土地集约利用评价方法研究综 述 [J]. 资源开发与市场, 2012, 28 (06) :529-533。

[4] 陈莹, 刘康, 郑伟元, 等. 城市土地集约利用潜力评价的应用 研究 [J]. 中国土地科学, 2002, 16 (4) :26-29。
[5] 林坚, 张沛, 刘诗毅. 论建设用地节约集约利用评价的技术 体系与思路 $[J]$. 中国土地科学, 2009, 23 (4) : 4-10。

［6］曹蕾, 梁启学, 李陶, 等. 工业园区土地集约利用评价探讨 - - 以重庆经济技术开发区为例 $[\mathrm{J}]$. 资源开发与市 场, 2009, 25 (1):31-33。

[7] 黄兴国. 建设用地集约利用评价探讨 [J]. 现代农业科 技, 2006 (10) : 192-193。

[8] 马玉梅, 马晓林. 高校教育用地集约利用评价指标思考 $[\mathrm{J}]$. 中国土地, 2015, (5) :37-38。

[9］陈思, 李淑杰, 范晓锋, 李青山. 长春市高校教育用地集约利 用评价及空间差异分析 $[\mathrm{J}]$. 东北师大学报 (自然科学 版）, 2016,48(01) :133-140。

[10] 李淑杰, 余娜, 范晓锋, 王极. 高校教育用地集约利用评价研 究——以吉林大学为例 $[J]$. 安徽师范大学学报 (自然科学 版), 2015, 38 (4) :358-364。

[11] 张亚丽, 翟晓艺, 蒙吉军, 黄珺嫦, 蔚霖. 高等学校老校区土 地资源集约利用评价研究 [J]. 地域研究与开 发, 2015, 34(3): 107-111。

[12] 李双异, 邵永东, 张晓东, 等. 辽宁省工业开发区土地集约利 用评价指标体系研究 [J]. 国土资源科技管理 2008, 25 (5) : 43-46。

[13] 伍国勇. 土地规划中建设用地集约与节约利用评价研究 -—以贵州省丹寨县为例 $[J]$. 经济论坛, 2006, 6 (6) : 31-34。

[14] 谢菲, 莫晓宇, 程震, 等. 基于TOPSIS法的建设用地集约利 用评价-—以江西省宜春市为例 $[\mathrm{J}]$. 农村经济与科 技, 2010, 21 (11):84-86。

[15] 宋小青, 麻战洪, 曾毅, 等. 基于综合集成赋权法的建设用地 集约利用时空评价 [J]. 资源调查与评价, 2007 (03) :55-59。

[16] 乔陆印, 周伟, 曹银贵, 等. 城市土地集约利用评价指标体系 研究 [J].生态经济, 2010 (6) :31-34。

[17] 蒋贵国, 周介铭, 孙国翰. 成都市高校土地利用集约利用评 价研究 [J]. 四川师范大学学报, 2012, 35 (2) :275-280。

[18］谭术魁, 周蔓. 武汉地区高校对土地集约利用政策的响应 $[J]$. 资源科学, 2012, 34 (1) : 143-149。

[19] 沈亚明, 刘金萍, 胥晓燕. 工业园区土地集约利用评价研究 - - 以重庆市茶园工业园区为例 $[\mathrm{J}]$. 国土资源情 报, 2012(2):38-43。

[20］李进涛, 谭术鬼, 汪文雄. 基于DPSIR模型的城市土地集约利 用时空差异的实证研究——以湖北省为例 $[\mathrm{J}]$. 中国土地科 学, 2009, 23 (3) : 49-54。

[21]覃莉, 陶晓龙, 周旭, 等. 中国高等学校建设用地标准研究 [J]. 中国土地科学, 2010, 24(10) : 41-45。 